\title{
Barriers to East Asian Integration: North East Asia-A Non-Region?
}

\author{
Uwe Wissenbach
}

Published online: 3 September 2013

(C) CEEUN 2013

\begin{abstract}
NE Asia seems like a non-region: it is less integrated than ASEAN, there is merely a socialisation process of China, Japan and Korea trilateral summitry but its institutionalisation is weak. At present they all try to minimise political constraints from economic inter-dependence and keep as much policy space as possible. NE Asia cultivates a sacred idea of sovereignty and nationalist exclusion of the 'Other'. A national conception of development has led to the consolidation of the nation state in Asia, able to exercise sovereignty as a pre-condition for co-existence and cooperation, but also for fierce competition. This prompts the question whether NE Asia actually needs regional integration at all: states may not be integrating regionally but internationalise because so much of their economic and security interactions are with outside partners. Thus concepts of regionalism which explain ASEAN integration processes do not apply to NE Asia. I argue that this lack of integration is due mainly to the moralization gap and victim-perpetrator roles and related defensive use of international law. The shadow of the 20th century is hanging over dynamic 21st century NE Asia. Hence, I believe that NE Asia's regional society will remain characterised by a two level dynamic: economic and social interaction will increase with limited spillover to the political level, which will seek control and proceed incrementally through functional intergovernmental multilateralism (trilateral FTA, education cooperation). A supranational institutionalisation is unlikely and subject to political decisions to overcome historical animosities, sacral interpretations of sovereignty and instrumental use of international law.
\end{abstract}

The paper expresses the private views of the author and can in no way be attributed to his employer.

\author{
U. Wissenbach $(\bowtie)$ \\ EU Delegation, Nairobi, Kenya \\ e-mail: Uwe.WISSENBACH@eeas.europa.eu \\ U. Wissenbach \\ Renmin University, Beijing, China
}


Keywords Integration · North East Asia · International Society · Multilateralism

\section{Introduction}

In this article I would like to explain the glaring lack of institutional regionalism in NE Asia by specific characteristics of the state system in the region which I describe as a regional society. I dismiss the idea of regionalisation through economic networks as insufficient. Neither is the US role in NE Asia as such the decisive obstacle to integration, but it is a consequence of the Cold War security overlay and has contributed to freezing old conflicts. The key issue is in my view a particular role-relationship that is neither enemy, nor rival, nor friend (Wendt 1999, pp. 2589). Rather I see a victim-perpetrator role relationship and a moralisation gap in which history and international law are the main battlegrounds. I argue that at present neither a Hobbesian, Lockean or Kantian culture of anarchy (Wendt 1999, pp. 246-50, 312), nor a Confucian culture of hierarchy that historically existed are fully capturing NE Asian regional society and its development. NE Asia will for the foreseeable future continue to 'muddle through' in what is best described as functional multilateralism.

Historically, NE Asia has been integrated from the 15th to 19th centuries in what I call a Confucian culture of hierarchy (an expression of which was the investiture and tribute system一册封朝贡). There are some differences among scholars on how this system really worked and some scholars reject the use of the term system and prefer to talk about merely relationships (Cha 2011). But clearly there has been a very different regional society in NE Asia in that period based on an idea of civilisation and morality rather than nation, territorial control and power compared to the so called Westphalian one in Europe, which is often considered as a global norm. Today, despite its relative cultural homogeneity and despite thickening networks of interdependence (Keohane 2002a, b), North East Asia is politically less integrated than ASEAN, let alone the EU. There is, however, a process (documented more than supported by a small secretariat opened in September 2011 in Seoul) of trilateral summitry and numerous meetings at ministerial and technical level between China, Japan and Korea. Another process is the Six Party Talks about North Korea's denuclearization which involve the outside powers US and Russia. However, earlier hopes that this diplomatic conference could be a nucleus for a regional security regime (Snyder 2008) have receded considerably since the talks stalled in 2008 and the DPRK nuclear programme continued unabated.

Many analysts of Asian or comparative regionalism naturally focus on ASEAN which has a central role in East Asian cooperation (Murray 2010; Yeo 2010; Bach 2011). However, NE Asia has a GDP much bigger than all of ASEAN combined, a larger population, a higher proportion of intra-regional trade, a stronger voice in international affairs and power resources of all kinds against which ASEAN pales in significance. When examining regional cooperation in NE Asia some of the frequently mentioned factors that supposedly hinder Asian integration can be discarded, such as the cultural and ethnic diversity of Asia and the weakness of 
states in the region. Yeo (2010, p. 332) develops Katzenstein's distinction of networked regionalism and institutionalist regionalism (see below) focusing on ASEAN arguing that 'different cooperation problems called for different institutional designs. The actual institutional designs for any regional project would depend on the goal of cooperation and type of problems that the project aimed to solve'. This understanding corresponds to my view of functional multilateralism (below) and puts aside the issues of identity (Acharya 2012). Yeo distinguishes the network concept where agents interact loosely within the network's realm and openly outside of it and emphasises that the network is free from the rigidity of a tight hierarchy. She then argues that such a concept fits ASEAN's weak states, their preference for track II diplomacy and that the network is driven by cities rather than nation-states (similarly Bach 2011, pp. 34-6). While this may be an accurate description of ASEAN (which was, however, founded for political rather than economic reasons), I have doubts that network integration can explain the situation in NE Asia although NE Asia's trade, investment and production networks are more interdependent than ASEAN's. NE Asia has strong states with a century old tradition of governments (at least trying to) control trade and private networks (Kang 2010, pp. 107-38), a strong focus on government diplomacy and the centrality of the nation-state as the defining institution of the regional society. However, political system differences are important in NE Asia, but apart from North Korea all are more or less market economies. Another key factor is the involvement of outside powers in the security field (the US mainly, but also Russia). Apart from the Six Party Talks the security relations are not multilaterally or regionally organised. However, NE Asian countries participate in wider Asian frameworks such as ARF, EAS that tend to crystallize around ASEAN.

Despite the lack of integration (and often even cooperation), NE Asia seems to be as successful as the EU measured in terms of material outputs-prosperity and peace. Over the last 30 years there has been no war and the countries of NE Asia ${ }^{1}$ (North Korea excepted) have seen their GDP in absolute and per capita terms multiply despite two financial crises. Three way trade between China, Japan and Korea reached 690 billion USD in 2011. It is on a par with the EU in terms of share of world GDP (almost $20 \%$ ), world exports (19\%) and three times more populous. $\mathrm{NE}$ Asia holds half of the world's foreign currency reserves.

\section{Regionalism, Regionalisation, Regional Society}

In 1999 China, Japan and Korea started a process of trilateral cooperation, but its institutionalisation is weak. The new Trilateral Cooperation Secretariat (TCS) in fact has no proper secretarial role. Its officials participate in summits and other meetings, but meetings are prepared and recorded by the host country and officials from each country's ministries, not the TCS (interview with officials from TCS 286-2012). The TCS has assembled and documented the trilateral cooperation process

\footnotetext{
1 I take NE Asia as China, Japan, North and South Korea. Russia is a special case, as part of its territory is in NE Asia and it has important interests and territorial issues in the region, however, it is also a European power. The US is present in NE Asia (alliances with Japan and ROK), but not a country of the region.
} 
and like a think tank plays a policy advice role. Despite strong economic interdependence not even an FTA among the three countries is in place (under negotiation since May 2012) while all countries have FTAs with partners outside the region. Even compared to ASEAN, NE Asia's cooperation is minimal. There are no normative or teleological milestones to map out a path to integration although there is a (rather pragmatic) vision for trilateral cooperation $2020 .^{2}$ It is therefore difficult to conceive of NE Asia as a region given the persisting security tensions, the importance of partners outside the region and the thin cooperation process.

Some authors therefore substitute regionalism by regionalisation built on capitalist networks (Katzenstein 2005, pp. 219-25; Yeo 2010) to deal with this institutional void. Acharya (2012, p. 12) holds: 'regionalism is no longer the monopoly of states... Regionalism is understood as different from regionalisation in the sense that the latter can be market driven and less political, although not entirely apolitical, than the former.'). Katzenstein (2005, p. 219) argues: 'European regionalism centers on state bargains and legal norms, Asian regionalism on market transactions and ethnic or national capitalism'. However, this regionalisation concept suffers from logical tensions between the global and the regional networks, the neglect of strong states and from bypassing the security issues. This is not to say that business networks, cities and provinces don't matter, but they do mostly in the area of trade and people to people exchanges. Businesses do play an important role in national preference formulations which have contributed to promoting trade and investment in the national development interest. However, they do not influence that much how NE Asia's international state system is constituted or generate an identity of 'regionness'.

In my view there is a contradiction between globalised economic networks (production chains) and regionalisation. If one measures regionalism through trade and investment flows, then NE Asia and Europe would form a region and so would China and Africa, but not China and India. From a regionalisation perspective the (global) openness that both Katzenstein (2005) and Yeo (2010) see as a characteristic of Asia's network regionalism is ambiguous. It prompts the question whether NE Asia actually needs regional cooperation at all or whether they are not competing between themselves. In other words, the nation states may precisely not be integrating regionally but simply internationalise globally because so much of their economic and political interactions and interests are with partners outside the region. The amount of foreign exchange reserves in USD and EUR rather than in regional currencies points to a similar conclusion as countries do not see the region as the guarantor of last resort of their economic security and interaction, but are ultimately self-reliant and focussing on the US and Europe internationally.

Where Katzenstein and Yeo are right is that market-driven economic interdependence and government cost-benefit calculations have supported (basic) liberal approaches to explain developments in the economic sphere in NE Asia. But these developments have not (yet?) led to any substantial institutionalisation (not even

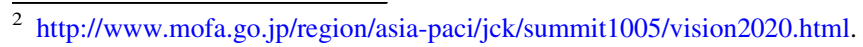


FTAs ${ }^{3}$ ). The role of international institutions and non-state actors remains limited by government policy. Whether regional FTAs produce the kind of institutional lock-ins is anyway doubtful, notably when comparing the competition between the European Communities and the EFTA in the early years of European integration that ended with the defection of most EFTA members to the EC/EU.

Thus concepts of regionalisation which may explain aspects of ASEAN integration processes do not necessarily apply to NE Asia where all the network interdependence has not led to any substantial regionalism. I therefore prefer to use the concept of regional society. This idea also better covers the security and the identity issues that are largely omitted in the regionalisation concept which is too focused on business and not enough on states.

\section{Security Issues}

The region has remained stable and has been without inter-state war for more than 30 years despite a power shift from Japan to China and the emergence of South Korea as an ambitious regional and global player. These developments occurred in a context of several unsettled territorial disputes (mainly small islets; Selden 2011) and tensions (missile and nuclear programme, naval battles) over North Korea (International Crisis Group 2010). This evolution defied predictions that Asia was ripe for conflict (Friedberg 1993). This has happened despite the inability to solve the lingering problems of WWII and in particular the San Francisco Treaty (Selden 2011; Ryu 2010), the Chinese civil war and the Korean War and may largely be due to the security role of the US in the region (Shambaugh 2008). Except for the DPRK, NE Asia is booming peacefully despite different political systems and despite the absence of any common institutions or deep agreements: even diplomatic relations - one of the classical institutions of international societybetween NE Asian countries are either recent or still outstanding. Alagappa (2003a) attributes this to an instrumental, but norms based security order (peaceful coexistence). Despite an obvious military rivalry between North Korea and South Korea and their respective allies as a consequence of the legacy of the Korean War, this peaceful co-existence order guaranteed by the US military presence in the region, includes all the countries. The military conflicts between North and South Korea have been limited to naval battles and skirmishes around the so-called Northern Limit Line (Roehrig 2009; ICC 2010) in what amounts to a 'territorial' conflict of sovereign control along a maritime demarcation line and most likely motivated by economic reasons (rich fishing grounds) and nationalist and instrumental use of international law. This is similar to other territorial issues in the region, most of which go back to the absence of clear provisions in armistice or peace treaties and disagreements over historical ownership.

\footnotetext{
3 Trade liberalisation was politically easier in a multilateral framework such as the WTO. But due to the stagnation of the WTO's DDA the issue of bilateral or trilateral FTAs is back on the political agenda in NE Asia, but also elsewhere.
} 


\section{Power and Security Cultures}

Sperling (2010) argues that national security cultures can evolve from Westphalian to post-Westphalian, like in the EU. He sees three developments: The first is a qualitative erosion of the state's ability and desire to act as a gate-keeper between internal and external flows of people, goods and ideas. The second is the voluntary acceptance of mutual governance between states and a resulting loss of autonomy in the face of common challenges or in order to enhance (common) welfare. The third development is the asymmetrical status of international law for the two types of states which qualify or modify the way sovereignty is perceived. There are few signs in NE Asia for any of these three developments. I argue that in NE Asia the development at the end of the 19th and during the first half of the 20th centuries actually was the opposite, a Confucian proto-community disintegrated into a Westphalian order and prompted a strong culture of national, sacred sovereignty and instrumental and defensive international law and national security that are now obstacles to integration. More recently the North Korean nuclear crisis has seen an at least temporary regression from a multilateral endeavour and cooperative mechanism, which was seen by some (Snyder 2008) as a step towards a cooperative (and thus more post-Westphalian) security mechanism to an 'old fashioned' antagonistic political and military confrontation. This is due to a hard-line security culture in the DPRK (military first) and a reversal of the 'sunshine policy' of South Korea back to a more traditional deterrence security culture in the face of the continued nuclear weapons programme of the DPRK and its military provocations (Cheonan and Yeonpyeong Island incidents). National security cultures in Japan and Korea have been strongly influenced by the US anti-communist Cold War stance which had the side effect of freezing the issue of Japanese war guilt in the face of the new communist threat (Kim 2010). Japan and Korea benefited from large scale US re-construction aid that promoted their rapid industrialisation. In both countries elites linked to the Japanese colonialisation of Korea and war effort continued to dominate politics until the end of the Cold War.

Alagappa (2003c) bases his extensive study of Asian security on a typology of international order (based on a critical assessment of the English School) as essentially rule-based interaction between states. This typology roughly corresponds to different schools of IR: Instrumental order (realist), normative-contractual order (rational-liberal) and solidarist order (republican liberalism/socialism) (Alagappa 2003c, p. 44). He further distinguishes pathways as distinctive methods to organise and sustain rule-governed interaction such as hegemony, balance of power, concert, collective security, international regimes and economic interdependence. Pathways to transformation into a solidarist order would be democratic peace or regional integration. However, he somewhat blurs his neat categorisation by arguing that they all co-exist and are inter-twined in particular because different countries have different understandings of the desirable order and pathways (Alagappa 2003d). In $\mathrm{NE}$ Asia it is quite evident that some countries have indeed very different perceptions about the (desirable or perceived) order for instance North Korea promotes an instrumental order dominated by military power, nuclear deterrence and maximum sovereignty unconstrained by economic interdependence. The US on 
the other hand remains attached to bilateral alliances while promoting liberal economic interdependence. China feels threatened by the democratic peace rhetoric and protects its regime through 'opaque deterrence', insistence on sovereignty and non-interference. These divergences obviously block some pathways, in particular those to integration, but have not spelt anarchy or major conflict (invalidating predictions that Asia was ripe for rivalry (Friedberg 1993).

Relations between NE Asian countries are overshadowed by territorial disputes and tensions due to school textbooks, monuments and nationalist representations of history or populist provocations of nationalism. While these disputes are often seen as issues of power politics they are in my view moralistic expressions of the underlying nationalism and sovereignism with international law and historical 'facts' used as weapons. National sovereignty is seen as sacred making compromises impossible. Every rock at sea becomes a holy symbol of the nation (Pinker 2011, p. 638) and a precedent for other claims (Dudden 2012). Nationalism is taught at school and territorial disputes are part of the curricula and both state and non-state actors are very active to keep them in the public conscience. It is therefore the Ministries of Education-not of Defence or Foreign Affairs-which hold the keys to overcoming what Pinker (2011, pp. 491-95, 525) calls the moralization gap i.e. the different viewpoints of perpetrators and victims, and to redefining the nation state by 'purging it of tribalist psychology'. US alliances with Japan and Korea have done nothing to overcome these issues, rather they have helped to freeze the unresolved issues during the Cold War (and beyond) (Kim 2010; Ryu 2010).

\section{NE Asia-A Regional Society in the Making?}

My understanding of regional society is based on a concept of what I call International Society 2.0, an update of the concept developed by the English School (for an overview Viotti and Kauppi 2012, pp. 239-74, 297-8, Hobson 2012, pp. 214-32 and a detailed discussion Bellamy (2005)). Bull and Watson (quoted in Viotti and Kauppi 2012, p. 240) defined international society as: "a group of states (or, more generally, a group of independent political communities) which not merely form a system, in the sense that the behaviour of each is a necessary factor in the calculations of the others, but also have established by dialogue and consent common rules and institutions for the conduct of their relations, and recognize their common interest in maintaining these arrangements".

International society 2.0 incorporates the transformation of the economic context since the 1980s (globalisation), the decline of violence and war in international relations (Pinker 2011) and, in keeping with the new regionalism agenda, regional societies with their different conceptions of key institutions, with the EU at one end of the spectrum and NE Asia perhaps at the other end (measured in degree of integration). My update is based on the following considerations:

- key institutions of what early theorists of international society reflected upon (sovereignty, war, balance of power, international law) have evolved significantly since. The importance of war as a means of politics, of anarchy and great power balance has much diminished since the end of the Cold War. Besides, 
these institutions were not the most relevant in the 'Chinese tribute system' which existed in parallel to the 'Westphalian system'. The concept needs to be made less euro-centric to become truly 'universal'.

- the (global) economy has to be brought in not only for its network capitalism, but also because state policy has prioritised the economy at the expense of the above 'classical' institutions (Buzan 2005; Falk 2005): Economic growth has become a top priority for North East Asia's development states (Kalinowski and Cho 2012) with only North Korea pursuing a military first policy. That largely explains the peaceful co-existence in the region. In Europe and more recently in NE Asia the collective and individual welfare of citizens has become an additional focus of the state and a source of domestic legitimacy (or legitimacy crisis). I would describe this as an economic culture of anarchy in the international society which comprises the economic interactions (trade, investment, etc. and related agreements and policies) and constraints (role of non-state actors, economic crises, climate change, etc.) on states. This economic culture of anarchy explains more about contemporary international politics than the anarchy constructed around inter-state violence only.

- Regional societies are 'miniature' worlds or state systems more or less embedded in a global international society. Globalisation ${ }^{4}$ has done much to break down the earlier boundaries between such self-contained 'worlds' on earth. Some regional societies have developed very distinct social structures and sometimes influenced others, sometimes not. Some have extended their social structures and culture to others, notably Europe through colonialism and imperialism. Regional societies can thus be shown to have been both parochial and potentially precursors or drivers of global change with 'globalisation' in its different guises imperial or benign as vector or facilitating condition. Europe's traditional 'Westphalian' system was initially a parochial attempt to redefine relations of European states but currently, whatever the intentions had been, most states subscribe to these originally parochial ideas, but the non-European, global history of the Westphalian system is fairly short.

Wendt (1999) - like the English School theorists-chose to focus on the state system and security when he developed his social theory of international politics because states are key actors in the regulation of organised violence which is one of the basic problems of international politics (Wendt 1999, p. 193), because states have in principle the monopoly on the legitimate use of organised violence (Wendt 1999, p. 213). However, if one follows Pinker's (2011) arguments the central role of violence in international politics is decreasing across the board (cf. also Bellamy 2005, p. 16: 'since the end of the Cold War there has been growing evidence of a shift towards a different type of society in which factors such as the balance of power and strategies of deterrence play less of a role'. Even Wendt (1999, pp. 2056) when he explains pluralist security communities and collective security comes to a similar conclusion that the Hobbesian culture of anarchy has become rare in

\footnotetext{
4 The industrial revolution arguably marks the beginning of globalization as a process bringing about a radical change in the use of energy and production processes and a steep and unprecedented rise in social development. For a very long-term context Morris (2011, pp. 490-554).
} 
today's state system and is being replaced by Lockean or Kantian ones. Adding an economic culture of anarchy modifies Wendt's theory to take account of these developments, but still recognises the constitutional importance of states in international politics.

The theory needs to be further nuanced as I find that in the study of NE Asia roles such as enemy, rivals and friends (Wendt 1999, p. 313) are complemented or transcended by victim-perpetrator roles which are linked to a moralisation gap between the NE Asian countries (see below). Interestingly, the earlier Chinese tribute system also focused more on regulation of a number of interactions (rituals and rules) and rarely resorted to war as a means of politics. Trade and profit also played a major role in it. Yet, here neither enemy, nor rival, nor friends describe these role relationships adequately. In the Confucian parlance of the time, family hierarchy (China the elder brother, Korea and Japan the younger ones) were used. Thus Western theory needs to be modified once more to capture NE Asian regional societies past and present.

The international society concept raises the problem of agreeing norms and rules for international society. The most challenging conundrum of NE Asia's regional society is to comprehend the (social) institutions that make it up despite the political system differences and historical and territorial contests. That is because a characteristic of an international society is a common understanding on norms and rules of interaction. At least one country in the region-North Korea (DPRK) regularly defies them, but even among the other countries in general the degree of commonality is low and seemingly confined to preservation of sovereignty, an instrumental, positivist use of international law and part cooperative, part competitive economic relations. What makes this all the more puzzling is that NE Asia has the experience of a very different regional society-the so called Chinese investiture and tribute system. In that bygone Confucian world the commonality was higher than today as illustrated in the Table 1.

Table 1 Equivalence of modern security community and Confucian society

Security community (Adler and Barnett 1998, Confucian society (Kang 2010 for details) pp. 30-35)

\begin{tabular}{|c|c|}
\hline $\begin{array}{l}\text { Members have shared identities, values and } \\
\text { meaning }\end{array}$ & Confucian state philosophy \\
\hline Relations are many-sided and face to face & $\begin{array}{l}\text { Various regulated diplomatic, tribute and trade } \\
\text { relationships which required face to face ritualistic } \\
\text { interaction }\end{array}$ \\
\hline $\begin{array}{l}\text { Long-term interests are pursued and often a } \\
\text { sense of altruism or responsibility develops }\end{array}$ & $\begin{array}{l}\text { Long-term interest in social stability, defence against } \\
\text { nomadic incursions and piracy and a cultivation of } \\
\text { civilisational achievement and refinement }\end{array}$ \\
\hline Peaceful resolution of conflicts & $\begin{array}{l}\text { Number of wars was very low and the case of the Imjin } \\
\text { War (1592-1597) showed a strong moral reaction } \\
\text { against aggression within the Confucian world }\end{array}$ \\
\hline Reciprocity & $\begin{array}{l}\text { Very essence of the investiture and tribute system and } \\
\text { in general relationships in the Confucian world }\end{array}$ \\
\hline
\end{tabular}

NE Asia's past is not its future-neither is it Europe's past 
Eurocentric theories have overlooked that in the past 300 years or so until the beginning of the 20th century, while Europe had developed its 'Westphalian society' (Osiander 2001), NE Asia had developed a very different international society - and a more peaceful one at that-with China (understood as civilisation not nation) at its apex. The 'investiture and tribute-system' was built on a hierarchy of civilisation and Confucian norms which partly at least regulated international exchanges, norms, diplomacy and trade (Kang 2010), although they were not always observed (Cha 2011). One could describe it as an international society built on formal hierarchy and informal equality with comprehensive (but differentiated Cha 2011) rules of international exchanges. Therefore, I propose to add to Wendt's (1999) 'euro-centric' ideal types of three cultures of anarchy (Hobbesian, Lockean and Kantian) a fourth ideal-type: the Confucian culture of hierarchy which was characterised by role relations of ritual, reciprocity and respect.

The old Sino-centric order collapsed under the onslaught of European and later Japanese imperialism. China, Japan and Korea hardly participated in diplomatic exchanges with European powers until they were forced to do so in the 19th century: as a result of the Second Opium War and the domestic Taiping rebellion the Qing Court agreed to the establishment of foreign consulates (Qu 2010, p. 67). Qu shows how in the 'short timespan of 100 years' China initially rejected the concept of sovereign equality that Europeans tried to impose on it in the 19th century and then became the champion of the 'sacred principle of national sovereignty' that it is today. The irony is that China in order to be able to sign the unequal treaties first required the recognition of its sovereign equality by the foreign invaders. Similarly, Korea used the Western concept to sever its links with the Chinese tribute system and bolster its independent nation-building only to become a victim of Japan's imperialism (Schmid 2002; Park 2010) to some extent with US support (Johnson 2011). Japan borrowed the Western ideas to become an imperial (anti-Western) power itself (Meiji reform).

NE Asia's centuries-old tradition of strong statehood, trade, diplomacy with shared norms of interaction and a rather homogenous cultural and moral heritage (Cha 2011; Kang 2010, Alagappa 2003a) is not now a source for contemporary integration projects in the region while Europe's war-torn history paradoxically did not hinder deep integration. Today a revival of the traditional Sino-centric culture of Confucian hierarchy as proposed for instance by Zhao (2005) is no longer conceivable, as China has lost the recognition of its civilisational superiority by the other countries. Sovereign equality has replaced hierarchy. The conundrum in the current regional context is of course that this formal equality masks an increasing dominance of China due to its enormous size (population, economy, military) compared to its neighbours.

NE Asia has not created either its own regional law system to transform sovereignty like the EU did, but very much uses international law as an instrument of national sovereignty. This attitude is linked to the utilitarian appropriation of sovereignty and international law as a tool to modernise and defend the 'new' nations at the beginning of the 20th century. The Qing Court for instance adopted international law in such a way, because sovereignty was upheld as inviolable by the Western countries, hence it could be used to better fight against the unequal treaties 
with the West's own legal concept. Adopting Western norms and institutions like international law was also the entry ticket into international society defined as it was then on Western terms replacing China's superior civilisation as the earlier defining institution for regional international society (Qu 2010, p. 72). Japan's Meiji reform and Korea's emancipation from China and later Japanese colonial rule followed a similar path (Schmid 2002).

NE Asian countries today participate in international law-making conferences which have moved from consent to consensus (Armstrong et al. 2007, p. 63) or even the supranational jurisdiction of WTO appellate bodies and dispute settlement panels (except North Korea). However, there is generally little support in NE Asia for liberal interpretations in international law beyond functional areas. The basic stance is pragmatic and interest-based and can be explained by the importance each country attaches to international law as an argument to justify its territorial claims as well as by the history of adopting international law as an instrument of defence of sovereignty.

In contemporary NE Asia this instrumental use of international law is still prevalent not least to uphold sacred sovereignty in territorial and maritime claims. The problem is of course that international law tends to refer to historical precedent most of which is disputed among the countries concerned (Park 2010; Dudden 2012). The 1951 San Francisco Treaty-deliberately or not-left many of the historical claims on various islands unresolved, sowing the seeds for continued tension in the East and South China Seas (Selden 2011).

The transformation of national sovereignty and the emergence of multi-level governance which are so characteristic of the European integration process (and partly of the pre-modern NE Asian regional society) are unlikely in NE Asia because of the conception of sacred sovereignty and nationalist exclusion of the 'Other'. Pinker (2011, p. 523 similar to Wendt 1999, p. 163, 229) shows that in human society there is an innate preference for one's group and for one's group to dominate others in a social hierarchy (that has to be un-learnt rather than learnt). This social dominance and hierarchy orientation inclines people and groups to patriotism, nationalism and even racism-factors that have been key causes of war in the past and remain causes for tensions and conflicts today in NE Asia. If nationalism is understood as an interaction between psychology, history and international law then it is one crucial 'switch' to determine the pathways to more or less integration, more or less cooperation. The examples of the EU on the one hand, based on the conscious rejection of nationalism (as an ideology not as a layer of identity) and of reconciliation to bridge the moralization gap, and of NE Asia on the other with its continuing conflicts along the 'moralization gap' illustrate that point.

\section{The Victim-Perpetrator Role Relationship}

The clues to this role relationship come from psychology and have been studied in a series of experiments for instance by Baumeister who noticed that people who perpetrate destructive acts never think they are doing anything wrong (Pinker 2011, pp. 488-497). Baumeister and others found that something in human psychology 
distorts interpretation and memory of harmful events. Moreover, each side to a dispute sincerely believes its version of the story and each side has assembled a historical narrative and a database of facts consistent with its belief. "Adversaries are divided not just by their competitive spin-doctoring but by the calendars with which they measure history and the importance they put on remembrance. The victims of a conflict are assiduous historians and cultivators of memory. The perpetrators are pragmatists, firmly planted in the present.' (Pinker 2011:493). Pinker calls this the moralization gap and underlines how disconcerting it is to discover that all sides to a conflict including 'nations waging world wars are convinced of their rectitude and can back up their convictions with the historical record.' (p. 494). The problem of the analyst of the moralisation gap is that taking a detached analytical stance makes his analysis overlap with the perpetrator's pragmatist stance, while a moral stance overlaps with that of the victim (Pinker 2011, pp. 495-6).

Pinker then goes on and links some of the motives for violence with this problem, for instance the quest for dominance which brought people to fight over 'nebulous claims to national preeminence including World War I' (p. 515) rooted in group identification or in the psychological term 'tribalism', the 'desire that social groups be organized into a hierarchy, generally with one's own group dominant over the other', an orientation that produces patriotism, racism national destiny, militarism when psychology and history interact (p. 523). This (modern) interaction is important as in the Confucian culture of hierarchy the pre-dominance of China did not produce 'tribalism' or 'militarism' until the end of the 19th century-although the countries in the Chinese world shared a common contempt for the barbarians (nomads and Westerners). Three things come together in the process: 'the emotional impulse behind tribalism; a cognitive conception of the "group" as a people sharing a language, a territory, and ancestry; and the political apparatus of government.' (p. 524). Finally ideology can make these things turning bad when 'ethnic groups long for states of their own, hope to unite with their diasporas in other countries, keep long memories of harms committed by their neighbours' ancestors while being unrepentant for harms committed by their own, and (...) mythologize one group's glorious history while excluding others from the social contract.' In the moralization gap 'perpetrators always have at their disposal a set of self-exculpatory stratagems that they can use to reframe their actions as provoked, justified, involuntary, or inconsequential' (p. 565).

I don't need to go into detail here, but these points sound familiar to any observer of contemporary NE Asian international relations, where Japan's colonisation of Korea, aggression and wartime atrocities in China and the perspectives of the victims and the Japanese exactly reflect that moralisation gap. Schmid (2002) also shows how group beliefs, nationalism and dominance have been literally created by 'historians' at the end of the 19th and beginning of the 20th centuries to replace the non-trialist Confucian order. Then the writing of history was not a scientific quest for facts, but a mission of storytelling and book-keeping of national achievements or humiliation at the hand of 'historical enemies' (the same as in Europe then). This tendency is still visible in history curricula in the region. No wonder 'national histories' have the competitive tendency to become longer and longer and reach 
further and further back in time, despite the fact that the concept of nation is a recent invention.

An apology is seen by Pinker (pp. 540-7) as a possibility to bridge the moralization gap, but he underlines that it cannot be 'cheap talk', but has to be a 'costly signal'. The gap can also be modulated if the relationship with the perpetrator is too important to sever and when the perpetrator has become 'harmless'. Pinker cites many instances of international apologies and reconciliation including the 1984 apology by the Japanese Emperor to the Korean President. Korean scholars do admit that Japan offered a series of apologies, but mostly they qualify them as not sincere enough or lacking a costly signal such as the legal recognition of responsibility and compensation (Park 2010; Selden 2011), hence the impossible expectation on international law to sort out moral issues. So why is the argument about the moralization gap fought with law rather than force? For one the US presence in the region and the balance of power linked to it is arguably a key factor in keeping a lid on tensions (but it also contributed to having them fester under the surface; Kim 2010; Ryu 2010). Another factor leads us back to the problem of interdependence and regionalism.

\section{Interdependence, Political Autonomy and Cooperation}

Alagappa (2003b, p. 20/1) stresses the importance of the consolidation of the nation state in Asia as modern states able to exercise sovereignty as a pre-condition for coexistence (similarly Qu 2010). Their focus on economic development has facilitated this consolidation. At the same time the focus on economic development has also spurred cooperation for mutual gain and facilitated the development of regional institutions as well as production networks. However, there is also strong competition. Globalisation is driven mainly by micro-economic and technological processes and new actors (Katzenstein 2005, p. 15, 37). These economic actors are not confined by territorial or cultural boundaries. Keohane (2002a, b, p. 206) emphasizes the transformative impact of globalization on governance. Alagappa (2003b, p. 21) argues, "market-based development and participation in the global capitalist economy have created further convergence in national goals and strategy that bind the Asian states to specific international norms and rules." i.e. regional international society. However, as I have argued in the introduction, the economic integration in NE Asia remains shallow despite an increasing interdependence. The Asian financial crisis reinforced convergence by discrediting the nationally defined developmental state (Kalinowski and Cho 2012). The question is whether such convergence is enough to lock-in NE Asian states into a pathway that eventually can transcend national boundaries and sovereignty in a neo-functionalist or institutional logic. Such a lock-in would at a minimum need shared, if not supranational institutions, political decisions taking the form of legal commitments and mechanisms to implement them (Pierson 1996).

Some scholars assume economic inter-dependence and cross-border flows of goods, services, capital and people under the conditions of globalisation automatically leads to more political cooperation, domestic change (towards 
democratisation) or even a new security order (Wan 2003). Others disagree. Acharya (2003, p. 214) holds that interdependence is not the crucial factor in Asian regionalism: "interdependence-based perspectives do not explain why and how ASEAN and SAARC emerged despite very low levels of subregional economic linkages. Nor do they explain why there has been no subregional institution in Northeast Asia despite a relatively high degree of economic interaction between China, Taiwan, Japan, the United States, and South Korea."

Shambaugh (2008, p. 26) argues that interdependence as such is also not enough to prevent conflict. Segal (1996) explicitly rejects such an assumption through a case-study of conflicts between China and SE Asian countries in the South China Sea. Countries have set up mechanisms to manage inter-dependence (e.g. in financial crisis situation) or common problems, but this did not lead to deep policy integration that Pierson (1996) is referring to i.e. these agreements and mechanisms are reversible and do not produce political spill-overs like in the EU. The main measures, financial regulation and controls and the accumulation of foreign exchange reserves, remained in the national logic. Cooperative policies like currency SWAPs and the Chiang Mai Initiative Multilateralisation are comparatively small and little used mechanisms.

At present, it appears that all countries in NE Asia are committed to peaceful co-existence but are trying to minimise political constraints from economic interdependence, keep their autonomy and ring-fence as large a policy space as possible within international and regional society. They do not compromise on the issuesincluding territorial disputes-linked to the moralization gap. In the security area the exceptions to autonomy are of course the Japan-US and RoK-US alliances which find their justification in the unresolved aftermath of the Korean War (absence of a peace agreement, persistent military threats and since the 1990s the DPRK nuclear weapons and missile programmes).

\section{Economic Cooperation, Security and Functional Multilateralism}

Asian nations do not consider foreign economic policy in isolation, but link it to security and other national interests Wan (2003, p. 288). Economic growth and (minimal) cooperation are thus part of a comprehensive conception of national security and hence promoting common prosperity benefits national interest and security while explaining the preference for accommodation over balancing (which is left to the US as it is cheaper and more trustworthy according to Buzan and Waever 2003). However, international cooperation in NE Asia remains essentially a state-based, national adaptation to economy-driven globalisation. Market-driven economic interdependence and government cost-benefit calculations have certainly supported corporate integration in NE Asia, but these developments have not led to any substantial institutionalisation and remain limited by the resilience of the nation-state.

Economic cooperation remains disconnected from the regional security-level and one can hardly speak of a commercial or democratic liberal peace regime in NE Asia. Normative agendas often linked to liberalism (Armstrong et al. 2007, p. 83, 
88) are largely absent. There is no explicit attempt to use trade relations as a vehicle to promote a regional political order to advance human dignity or a peace regime that bridges the moralization gap. A democratic peace community is also not on the agenda. For one, there is still a divide between democratic and non-democratic states and no project to bridge this divide (such as the CSCE process in Cold War Europe), but more intriguingly, not even the two liberal democracies and hypothetical allies_-Japan and South Korea-cooperate on building one. This is mainly due to the moralization gap which persists despite economic interdependence and a power shift to China (that might have spurred a rapprochement between Japan and Korea). The victim-perpetrator relations clearly transcend the roles of enemies and friends-while Korea and Japan are not enemies, they are both US allies but cannot become friends. In the end merely the minimal norm of peaceful co-existence underpins the burgeoning economic exchanges and cooperation attempts in NE Asia.

\section{Conclusion}

So, if there has been no armed conflict as realists predicted, nor interdependence to explain sufficiently the peaceful development and increasing prosperity of NE Asia in the absence of regional integration, I suggest to conceive of NE Asia as a regional society in which minimal norms are agreed and internationalisation is a little institutionalized or legalised process to catch up with globalization and economic interdependence. In this regional society the moralization gap is the main obstacle to cooperation and integration. The evolving trilateral cooperation between China, Japan and Korea can best be described as functional multilateralism. Functional multilateralism respects sovereign equality (pooling resources not pooling sovereignty or domesticating international law) and avoids political integration. It is compatible with the role relationship linked to the moralization gap, because it avoids the political and historical issues and firmly deals with issues in the economic culture of anarchy. Functional multilateralism focuses on enhancing legitimacy by output efficiency.

Clearly, regionalisation in NE Asia is a lesser priority than cultivating national sovereignty and identity down to outright denial of commonality. Therefore, it is not institutional and not based on international law to the point that NE Asia is almost a non-region compared to other regional endeavours like ASEAN, the African Union or Latin American regionalism not to mention the EU. Hence, I believe that NE Asia's regional society will for some time to come remain characterised by functional multilateralism and a two level dynamic: economic and social interaction will continue to increase with limited spill-over to the political level. Governments will seek control and proceed only incrementally through functional intergovernmental integration with projects such as a trilateral Free Trade Agreement or education cooperation (Campus Asia). A supranational level or thick institutionalisation seems a remote prospect and subject to a political and normative decision to overcome nationalism historical animosities, sacral interpretations of sovereignty and defensive international law. This is not an issue of 'rational' (Western liberal) 
cost-benefit calculations, but one of identity and related role relationships in the shadows of the past.

\section{References}

Acharya A (2003) Regional institutions and Asian security order: norms, power, and prospects for peaceful change. In: Alagappa M (ed) Asian security order. Instrumental and Normative Features. Stanford University Press, USA, pp 210-240

Acharya A (2012) Comparative regionalism: a field whose time has come? Int Spect 47(1):3-15

Alagappa M (ed) (2003a) Asian security order. Instrumental and Normative Features. Stanford University Press, USA

Alagappa M (2003b) Introduction. In: Alagappa M (ed) Asian Security order. instrumental and normative features. Stanford University Press, USA, pp 1-30

Alagappa M (2003c) The study of international order. an analytical framework, In: Alagappa M (ed) Asian security order. Instrumental and normative features. Stanford University Press, USA, pp 3369

Alagappa M (2003d) Constructing security order in Asia. Conceptions and issues. In: Alagappa M (ed) Asian security order. Instrumental and normative features. Stanford University Press, USA, pp 70105

Adler E, Barnett M (eds) (1998) Security communities. Cambridge University Press, Cambridge

Armstrong D, Farrell T, Lambert H (2007) International law and international relations. CUP, Cambridge

Bach D (2011) Organisations régionales et régionalisation : crise en Europe, essor au-delà. In: Bertrand B, Dominique V (eds) Nouveaux acteurs, nouvelle donne, l'Etat du monde 2012. La Découverte, Paris, pp. $29-38$

Bellamy AJ (2005) International society and its critics. Oxford University Press, Oxford

Buzan B, Waever O (2003) Regions and powers. The structure of international security. Cambridge University Press, Cambridge

Buzan B (2005) International political economy and globalization. In: Bellamy AJ (ed) International society and its critics. Oxford University Press, Oxford, pp 115-134

Cha H (2011) Was Joseon a model or an exception? Reconsidering Tribut Relat During Ming China Korea J 51(4):33-58

Dudden A (2012) Japan's border disputes: Dokdo at the center of bigger things. ASAN Institute for Policy Studies Issue Brief $N^{\circ} 19$ (Feb. 6, 2012)

Falk R (2005) (Re)Imagining the governance of globalization. In: Bellamy AJ (ed) International society and its critics. Oxford University Press, Oxford, pp 195-203

Friedberg AL (1993) Ripe for rivalry: prospects for peace in a multipolar Asia. Int Secur 18(3):5-33

Hobson JM (2012) The eurocentric conception of world politics; Western International Theory. Cambridge University Press, Cambridge, pp 1760-2010

International Crisis Group (2010) North Korea: The Risks of War in the Yellow Sea, Asia Report N 198

Johnson AS (2011) Early American perceptions of Korea and Washington's Korea policy, 1882-1905. Korea J 51(4): 110-131

Kalinowski T, Cho H (2012) Korea's search for a global role between hard economic interests and soft power. Eur J Dev Res 24(2):242-260

Kang DC (2010) East Asia before the West. Five centuries of trade and tribute. Columbia University Press, New York

Katzenstein PJ (2005) A World of regions. Asia and Europe in the American Imperium. Cornell University Press, Ithaca and London

Keohane RO (2002a) Power and governance in a partially globalized world. Milton Park, Routledge

Keohane RO (2002a) Global governance and democratic accountability. http://unpan1.un.org/intradoc/ groups/public/documents/apcity/unpan034133.pdf. Accessed 9 Feb 2012

Kim DC (2010) Korea's movement to settle the issues of the past and peace in East Asia. Korea J 50 (4):152-185

Morris I (2011) Why the West rules - for now. The Patterns of History and what they reveal about the Future. Profile Books, London 
Murray P (2010) Comparative regional integration in the EU and East Asia: moving beyond integration snobbery. Int Politics 47(3/4):308-323

Osiander A (2001) Sovereignty, international relations, and the Westphalian Myth. International Organization. 55(2):251-287

Park PK (2010) Discussions concerning the legality of the 1910 "Annexation” of Korea by Japan. Korea J 50(4):13-41

Pierson P (1996) The path to European integration: a historical institutionalist analysis. Comp Political Stud 29:123-163

Pinker S (2011) The better angels of our nature: the decline of violence in history and its causes. Allen Lane, London

Qu C (2010) 中国人与主权观念: 从被迫接受到主动建构 (The Chinese and the Sovereign State: From Passive Receiving to Proactive Construction). World Econ Politics 6/2010:64-78

Roehrig T (2009) North Korea and the Northern limit line. North Korean Rev (Spring 2009): 8-22

Ryu J (2010) Several present conditions defining 100 years of Japan's annexation of Korea. Korea J 50 (4):127-151

Schmid A (2002) Korea between empires, 1895-1919. Columbia University Press, New York

Segal G (1996) East Asia and the "Constrainment" of China. Int Secur 20(4):107-135

Selden M (2011) Small islets, enduring conflict: Dokdo, Korea-Japan Colonial Legacy and the United States. Asia Pac J 9(17). Posted to http://www.japanfocus.org. Accessed 20 July 12

Shambaugh D (2008) International relations in Asia. The two-level game. In: Shambaugh D, Yahuda M (eds) International relations of Asia. Rowman \& Littlefield, Lanham, pp 3-31

Snyder S (2008) Prospects for Northeast Asia security framework. Korea Economic Institute, Conference Paper, Washington, DC, 15 October 2008

Sperling J (2010) The Post-Westphalian State, National Security Cultures, and Global Security Governance. EU-GRASP Working Paper No. 15

Viotti PR, Kauppi MV (2012) International relations theory, 5th edn. Pearson, Glenview

Wan M (2003) Economic interdependence and economic cooperation. Mitigating conflict and transforming security order in Asia. In: Alagappa M (ed) Asian security order. Instrumental and normative features. Stanford University Press, USA, pp 280-310

Wendt A (1999) Social theory of international politics. Cambridge University Press, Cambridge

Yeo LH (2010) Institutional regionalism versus networked regionalism: Europe and Asia compared. Int Politics 47(3/4):324-337

Zhao T (2005) 天下体系。世界制度哲学导论。Jiangsu Jiaoyu Chuban She, Nanjing 